\title{
A HYBRID RECONFIGURABLE COMPUTER-INTEGRATED MANUFACTURING CELL FOR THE PRODUCTION OF MASS CUSTOMISED PARTS
}

\author{
N. Hassan ${ }^{1 *} \&$ G. Bright ${ }^{2}$ \\ Department of Mechanical Engineering \\ University of KwaZulu-Natal, South Africa \\ ${ }^{1}$ nazhassan@webmail.co.za; ${ }^{2}$ Brightg@ukzn.ac.za
}

\begin{abstract}
Current manufacturing environments do not possess the flexibility required for massproducing custom parts. A solution - forming a hybrid manufacturing system that encapsulates computer-integrated manufacturing $(\mathrm{CIM})$ cells with reconfigurable manufacturing system (RMS) techniques - is proposed to facilitate the production of mass customised parts. The reconfigurable CIM hybrid cell possessed manufacturing conditions such as key RMS characteristics and CIM capabilities, controlled simultaneously by its software and hardware. Through intelligent agent-based architecture, it executed various operations, ranging from intelligent production scheduling and mechanisation of hardware to synchronisation of the cell components.
\end{abstract}

\section{OPSOMMING}

Huidige vervaardigingsomgewings besit nie die nodige aanpasbaarheid om doelgemaakte produkte in grootmaat te produseer nie. 'n Oplossing, waarin 'n hibriede vervaardigingstelsel saamgestel uit rekenaargeïntegreerde vervaardigingselle ("CIM cells") met herkonfigureerbare vervaardigingstelseltegnieke ("RMS techniques"), is voorgestel om die produksie van doelgemaakte produkte op grootmaat te fasiliteer. Die herkonfigureerbare hibriede sel toon vervaardigingstoestande wat tegelykertyd deur beide die programmatuur so wel as die apparatuur beheer word. Die sel het, deur die gebruik van intelligente agentgebaseerde argitektuur, werksaamhede uitgevoer wat wissel van intelligente produksieskedulering, meganisasie van apparatuur, tot sinchronisasie van die selkomponente.

\footnotetext{
${ }^{*}$ Corresponding author
} 


\section{INTRODUCTION}

Manufacturing industries at present are unable to produce mass customised parts easily. Modern manufacturing technologies provide more flexibility, but are very costly to implement. The dynamic and competitive market for customised parts arises directly from diversified customer needs. Custom parts also need to be cost effective and of good quality in order to produce customer satisfaction. This approach of focusing production on customer satisfaction also generates beneficial market-related results for a manufacturer.

This inability to manufacture cost effective mass customised parts inspired the research and development of a hybrid manufacturing cell. Research into computer-integrated manufacturing (CIM), which includes flexible manufacturing systems (FMS) and reconfigurable manufacturing systems (RMS), analysed each of them for their ability to produce mass customised parts. Analysed characteristics based on CIM, FMS, and RMS were used to define the ability of the hybrid cell to produce custom parts at near mass rate. This hybrid cell, termed a reconfigurable computer-integrated manufacturing (RCIM) cell, was exposed to priority scheduling events for irregular part geometries. This irregular part geometry flow represented custom parts, and indirectly generated the autonomous reconfiguration of the material handling system.

The RCIM cell's architecture can be divided into software and hardware. At a software level it consists of reconfigurable software computing abilities [1]. Robotic vision software and programmable languages form the cell's software architecture. At a hardware level, the cell is equipped with state-of-the-art six-axes robotic arms, an automatic storage and retrieval system (ASRS), conveyors, an automatic guidance vehicle (AGV), and various sensors that perceive the manufacturing environment. The integration of the CIM cell software and hardware at a reconfigurable level is able to provide certain key RMS characteristics while operating in a manufacturing environment $[1,2]$.

The objectives of the research are:

- $\quad$ To provide a RCIM cell that is able to produce mass customised parts.

- To increase the variety of parts (customised parts) produced within a manufacturing cell.

This paper discusses the use of prioritising scheduling for different part configurations using a RCIM cell. It provides solutions for broadening the operation space to produce mass customised parts in a hybrid RCIM cell environment. It also deals with the various aspects of product engineering that integrate manufacturing functionalities and optimise production for this hybrid cell.

\section{LITERATURE REVIEW}

The literature is subdivided into various categories. It provides an insight into the various theoretical and physical applications used in manufacturing. It covers manufacturing information about CIM, RMS, FMS, and mass customisation. Combining these applications, it forms a methodology for the implemented hybrid RCIM cell.

\subsection{Existing manufacturing technologies}

\subsubsection{Computer-integrated manufacturing}

CIM provides the architecture for manufacturing companies to be successful in today's competitive market. As a programmable automated process, CIM involves the integration of many manufacturing functionalities. These include computer-aided design (CAD), computeraided manufacturing (CAM), automated material handling (AMH), computer numerical control (CNC), ASRSs, and AGVs [3, 4]. In addition, CIM is an approach to forming a fundamental management and manufacturing strategy. It integrates manufacturing facilities and systems with the use of computers and their peripherals [5]. 
$\mathrm{CIM}$ is also able to undergo more frequent production changes, increase the ability to produce complex parts with accuracy and repeatability of a high degree, reduce inventory levels, and provide shorter lead times in manufacturing. CIM also provides improved machine utilisation, thus reducing the purchase of manufacturing equipment [6]. From an organisation-based perspective, CIM provides the integration to automate the flow of information among interconnected processes. These include tooling, scheduling, and manufacturing. At an organisational level it includes material handling, production, and inventory control [7].

\subsubsection{Reconfigurable manufacturing systems}

According to Koren \& Ulsoy [1], an RMS is a system designed for the rapid adjustment of production capacity and functionality in response to new circumstances, by rearranging or changing its components.

RMSs involve the combination of FMSs and dedicated manufacturing lines [8]. RMSs provide flexibility not only in the production of part variety, but in providing changes within the system. An RMS is designed with the use of modules (hardware and software) that rapidly reconfigure in a cost-effective manner $[1,2]$. It also allows rapid production of dissimilar product families in the shortest time and at the lowest cost, without reducing quality [9]. RMSs can adapt to short product life cycles and unpredictable market demands [8]. In relation to technological advancements and capacity demands, RMS systems can adjust to these needs by removing, adding, or modifying certain software, controls, process capabilities, or machine arrangements. RMSs are designed to be open-ended, allowing them to be upgraded, enhanced, and reconfigured [2].

Reconfiguration can be implemented in various forms. These include reconfigurable computing, reconfigurable material handling, and self-reconfigurable robots. Reconfigurable computing is the ability to configure a machine often to execute different functions [1]. Reconfigurable material handling and grasping mechanisms are devices that enable the handling of parts of various sizes and shapes. Self-reconfigurable robots are able to perform various functions by changing their physical connections without any external assistance [1].

The RMS approach provides many key characteristics at a software and hardware level. Some of these are summarised below $[1,2,8,10]$ :

- Modularity: Modularity functionalities can be either software- or hardware-based. Upgrading modules to add applications decreases the life-cycle cost of the system, reduces lead time, and increases product variety.

- Integrability: Provides communication and integration of a manufacturing system at a mechanical and control level.

- Customisation: The ability to design hardware, controls, and system capabilities that match the needs to produce a specific product family.

- Diagnosability: Provides the function to determine the efficiency of the system by applying monitoring and reliability techniques.

- Convertibility: The ability of a manufacturing system to change its setup in order for it to produce future products. During this changeover, rapid response and short conversion times of a manufacturing system are vital.

\subsubsection{Flexible manufacturing systems}

An FMS is a highly automated group technology (GT) machine cell that is based on CIM technology [11]. It is controlled via a distributed computer system, and consists of a group of processing workstations (such as CNC machine tools) that are interlinked with an automated material handling and storage system. An FMS has the capacity to respond to changing demand patterns, including a mix of part styles and production quantities $[3,10]$.

For a manufacturing system to be flexible, it must have the ability to recognise and differentiate between the incoming parts or product styles that need to be processed. It must also provide a quick changeover of operating instructions and setup of equipment [3]. 
Some of the added benefits of implementing an FMS approach include [3, 10]:

- Enhanced machine usage

- Reduction in inventory

- Reduction in lead times

- Quick response to changes within the manufacturing system that result from part design changes, production schedule changes, product mix, cutting tool failures, and machine breakdowns

- Increased management control of the complete manufacturing process

- Reduced need for factory floor space

\subsection{Mass customisation}

Mass customisation is the technology and systems used to deliver goods and services to meet individual customer needs with near mass production efficiency. To emphasise this definition, mass customised products should be of high volume and comparably priced to standard products [12]. Mass customisation relates to the concept 'build to order', which enables products to be manufactured once customer orders have been placed. Once customer orders have been received, the procedure of ordering material or components (product modules for assembling) follows. This concept has many positive factors, including the reduction of resource waste and inventory levels, which provides positive feedback about the financial performance of a company $[13,14]$.

\section{MODEL DESCRIPTION}

The implemented RCIM cell included the integration of CIM, FMS and RMS shown in Figure 1. This implemented interface was formed by extracting specific aspects from existing manufacturing technologies (as detailed in section 2.1). Table 1 shows a summary of the differences and similarities of RMSs and FMSs. RMSs are able to produce part families, but lack the ability to initiate the production of mass customised products. FMSs, on the other hand, operate within a job shop environment where product variety is unlimited. Generating an unlimited variety of parts requires expensive manufacturing equipment. The implemented RCIM cell, in contrast to RMSs and FMSs, provided sufficient flexibility and reconfigurability to facilitate the production of mass customised parts.

The developed RCIM cell was designed to possess equipment with sufficient flexibility and reconfigurability to manufacture parts that were standard to the available part library. This approach prevented wasted flexibility that would arise from costly manufacturing equipment. Table 1 shows $[15,16]$, the RCIM cell costs more than an RMS but less than an FMS. The RCIM cell was adjustable in its system and machine structure. System focus was driven from the available custom part library that was available to customers.

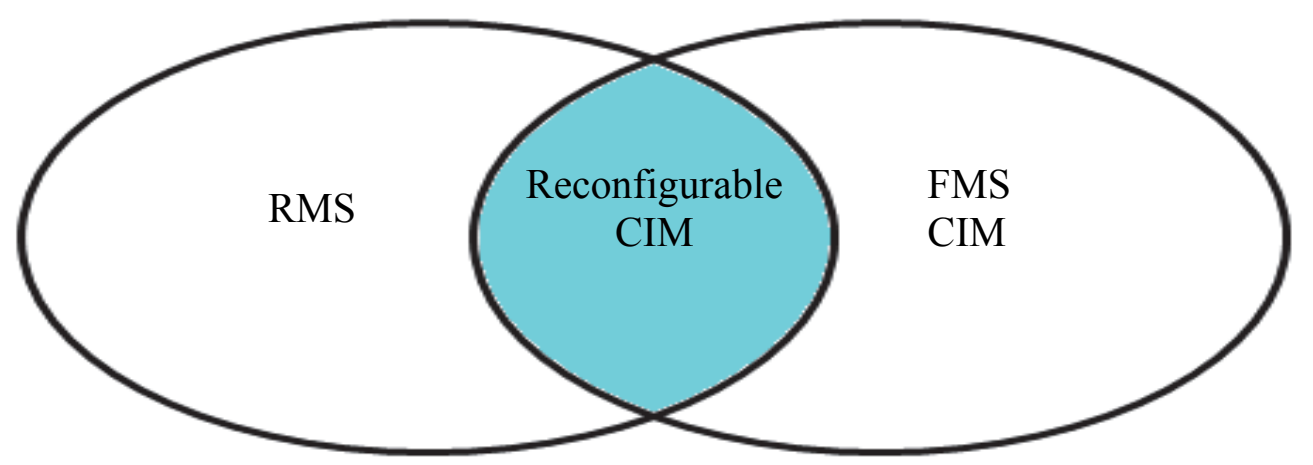

Figure 1: Integration of RMS into an FMS, CIM environment 


\begin{tabular}{|l|l|l|}
\hline & RMS & FMS \\
\hline System structure & Adjustable & Adjustable \\
\hline Machine structure & Adjustable & Fixed \\
\hline System focus & Part family & Machine \\
\hline Flexibility & Customised & General \\
\hline Simultaneous operating tools & Yes & No \\
\hline Cost & Intermediate & High \\
\hline
\end{tabular}

Table 1: Similarities and differences between RMS and FMS

This RCIM cell provided a modern approach to producing mass customised parts. The cell primarily operated from an intelligent software system. This enabled mutual data communication for production monitoring and system changeover. The cell architecture was composed of integrated hardware and software systems. Each system consisted of modules and components, which provided unified and synchronised functionality of the RCIM cell in a volatile scheduling environment. To characterise this approach in the cell, some of the key RMS characteristics were implemented into the cell's software and hardware architecture. At a systematic component level, the RCIM cell consisted of the following hardware and software [14]:

\subsection{Hardware level}

- An ASRS that performed quick and precise operations. It allowed for raw material storage, and provided dynamic scheduling capabilities. Increased throughput, control over inventories, and an increase in customer service were some of the benefits of implementing an ASRS within the manufacturing cell $[3,17]$.

- RMS technology is still being researched. Current RMS platforms are not robust or responsive enough in their control to be used in the RCIM cell. A six-axes selfreconfigurable Fanuc robotic arm with high axis speeds, repeatability, and vision capabilities was therefore used to represent RMS technology in the RCIM cell. A fixed camera that was integrated with the robot controller along the material handling system provided rapid feedback to the vision software of part detection for processing. Image processing of part geometries sent feedback to the robot controller for self-reconfiguration of its end effector in order to manipulate different part geometries. The robotic arm possessed reconfigurable modules for diverse material handling capabilities (Figure 2). With the use of gripper modules that rested on a gripper holding table, the robot automatically self-reconfigured its end effector to the required module. This was achieved through programming the robot's axes and its output signals to external devices (solenoid valves that control gripper modules). Gripper modules allowed for different part geometries to be picked and placed. A two-finger gripper module (Figure 2) was used for rectangular part geometries, while a three-finger gripper module (Figure 3 ) facilitated handling of circular part geometries.

- Responsive, cost-effective, light-dependent resistor sensors for part detection along the material handling system. It formed a communication between the ASRS, conveyor, and robotic vision system. A rapid response in tracking parts synchronised the scheduling operations and provided a quick system changeover.

- A CNC milling machine.

- An AGV (as depicted in Figure 4 [18]) provided distributed process integration within the material handling system (ASRS and conveyor system). A specific functionality of the AGV was its integrated local navigation capability [18]. 


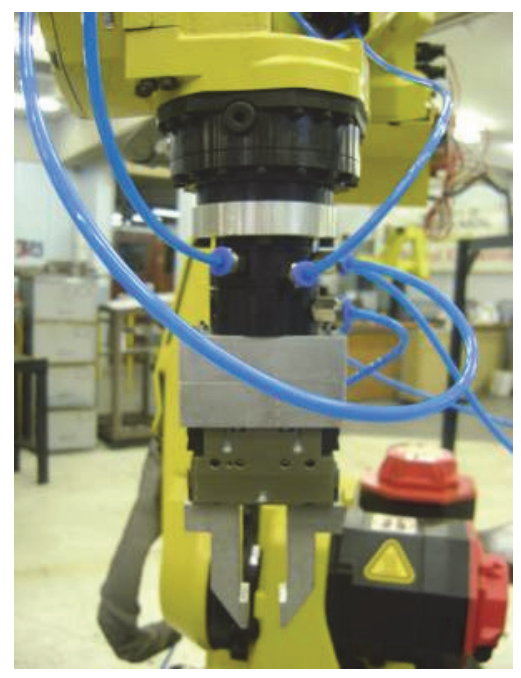

Figure 2: Robotic arm end effector with reconfigurable tool changer and two-finger gripper

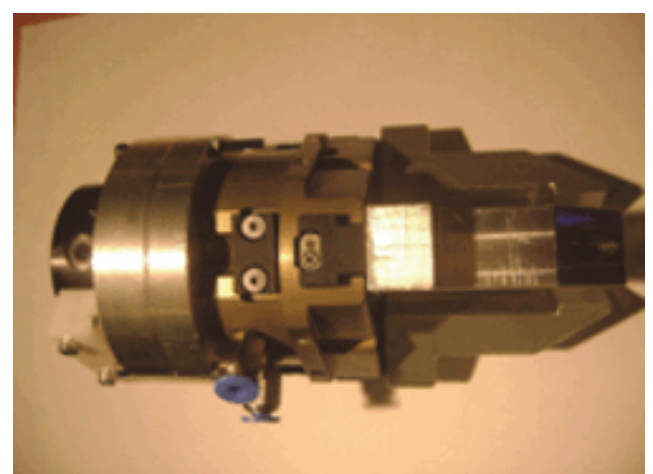

Figure 3: Three-finger gripper module

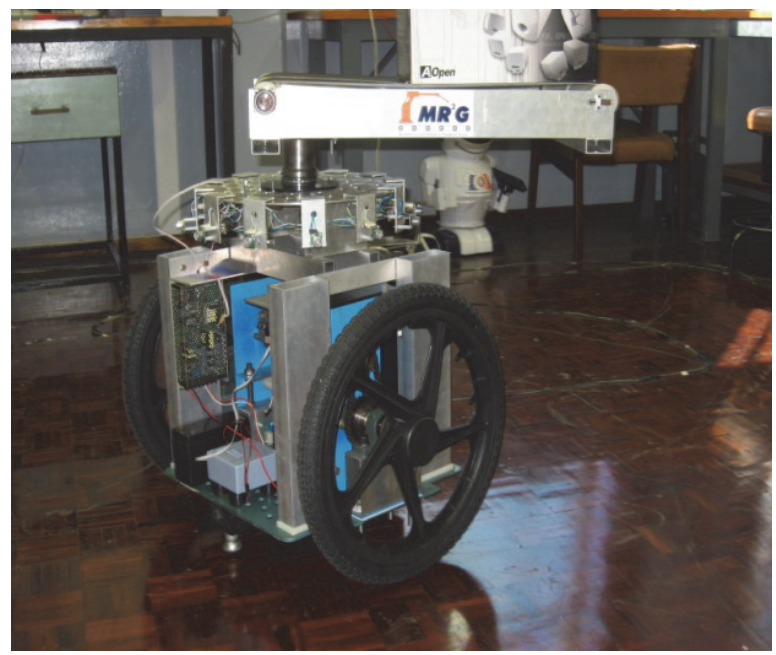

Figure 4: AGV for distributed process integration 


\subsection{Software level}

- Programmable language software compilers (Visual Basic and C) initiated scheduling algorithms and were able to make intelligent decisions. Visual Basic was primarily used to create the master control program, which had a graphical user interface (GUI) for customer product selection (orders). A customer order was further defined by entering the number of parts per order and the time needed to process the order. The GUI also provided real-time communication between the hardware (the sensors). The $C$ programming language was used in embedded programming operations that facilitated hardware mechanisation. This software was based on reconfigurable computing capabilities, which caused the physical configuration of the manufacturing cell to perform varying functions that matched the architecture needed to produce a specific customised product.

- iRvision software (Figure 5), supplied with the robotic arm vision system, enabled 2D robotic vision capabilities. Functionalities included responsive robotic guidance, image process feedback, an interface for teaching different part geometries, and simple calibration methods.

At a control level, the hardware and software mentioned above were integrated with data acquisition and microcontroller technologies. Its functionality at a unified level was precise, rational, and flexible. It also provided rapid response in a real-time environment. These functionalities helped to optimise dynamic schedules by being able to reconfigure the cell architecture for demand fluctuations and product variability. Reconfiguration of the RCIM cell was designed to operate according to the key RMS characteristics. It enabled the manufacturing system to convert rapidly when different products were introduced, to adjust capacity rapidly, to integrate technologies, to increase product variety, and to adapt to erratic quantities. It also reduced setup times and equipment [2].

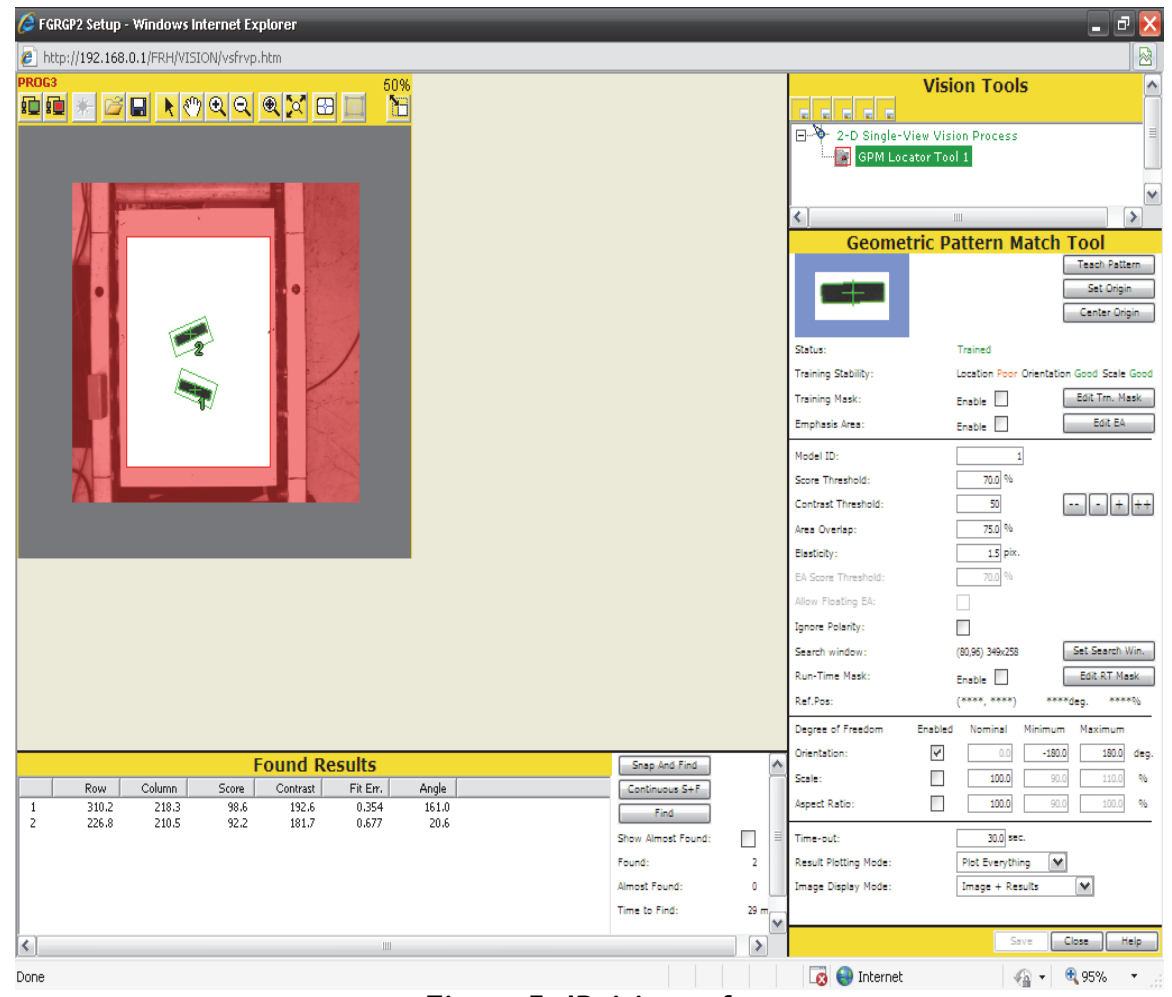

Figure 5: IRvision software 


\section{EXPERIMENTAL PROCEDURE AND RESULTS}

Based on the physical RCIM cell, a simulated version of the manufacturing cell was generated (as seen in Figure 6). Simio, a software program for manufacturing, was used to perform the simulation. To imitate a real event scenario with various customer orders, a production schedule was initiated. This dealt with prioritising schedules in a stochastic environment that consisted of frequently-changing products and quantity demands. This approach moved away from the conventional sequential method of scheduling production.

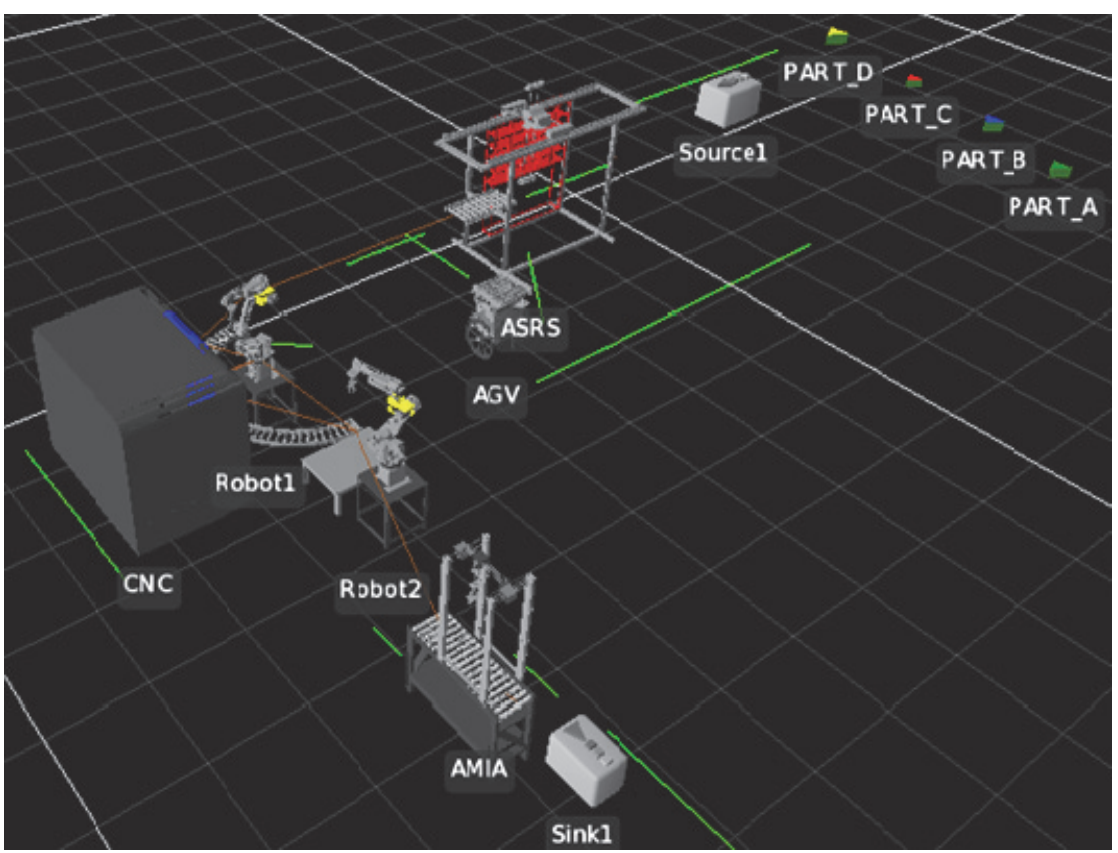

Figure 6: Simio 3D overview of the HRCIM cell

Four parts (A, B, C, D) from a mass customised level were randomly chosen for experimental purposes. Parts A and B had similar geometries and CNC processing requirements. Parts $C$ and $D$ also had these characteristics (similar geometries and CNC processing times), but differed from parts A and B. All four parts formed the standard library of custom parts that were available to customers. The parts had different geometries, process plans, and machining requirements. Production time for each part was taken by combining CNC simulations and material handling times. Each customer order contained a variable number of parts and due times. A production schedule was initiated that was dependent on a number of variables. This included parts per order, part processing times, and due dates. Table 1 contains the variables for four different customer orders [14].

\begin{tabular}{|c|c|c|c|c|c|c|}
\hline Customer order no. & $\mathbf{P}_{\mathbf{i}}$ & $\mathbf{P}_{\mathrm{t}}$ & $\begin{array}{c}\mathrm{PT}_{\mathrm{p}} \\
\text { (min) }\end{array}$ & $\begin{array}{c}\mathrm{T}_{\mathrm{d}} \\
\text { (hours) }\end{array}$ & $\begin{array}{c}\mathrm{T}_{\mathbf{i}} \\
\text { (hours) }\end{array}$ & $\begin{array}{c}\mathrm{T}_{\mathrm{f}}=\mathrm{T}_{\mathrm{d}}-\mathrm{T}_{\mathbf{i}} \\
\text { (min) }\end{array}$ \\
\hline $\mathbf{1}$ & 10 & $\mathrm{~A}$ & 16.090 & $14: 00$ & $8: 00$ & 360 \\
\hline $\mathbf{2}$ & 5 & $\mathrm{~B}$ & 8.513 & $13: 00$ & $8: 20$ & 280 \\
\hline $\mathbf{3}$ & 5 & $\mathrm{C}$ & 13.807 & $15: 30$ & $10: 00$ & 330 \\
\hline $\mathbf{4}$ & 15 & $\mathrm{D}$ & 8.79 & $15: 30$ & $9: 00$ & 390 \\
\hline
\end{tabular}

Table 2: Customer order and part process variables

where: $P_{i}=$ number of parts per order; $P_{t}=$ part type; $P T_{p}=$ time to produce each part; $T_{d}=$ time due; $T_{i}=$ time order was initiated; $T_{f}=T_{d}-T_{i}=$ time to due date. 
In scheduling a process, each order was given a coefficient of priority $\left(C_{\text {priority }}\right)$. Figure 7 contains results for the priority levels for each customer order. The lower the coefficient of priority for a particular order, the higher its priority for processing. From the results achieved, customer order number one had the highest priority, while customer order number two was assigned the lowest priority $[14,19]$.

$C_{\text {priority }}=\frac{T_{f}}{P T_{o}}$

$\mathrm{C}_{\text {priority }}=$ coefficient of priority for each order;

$\mathrm{PT}_{\mathrm{o}}=$ time to produce a particular order $=\mathrm{PT}_{\mathrm{p}} \times \mathrm{P}_{\mathrm{i}}$

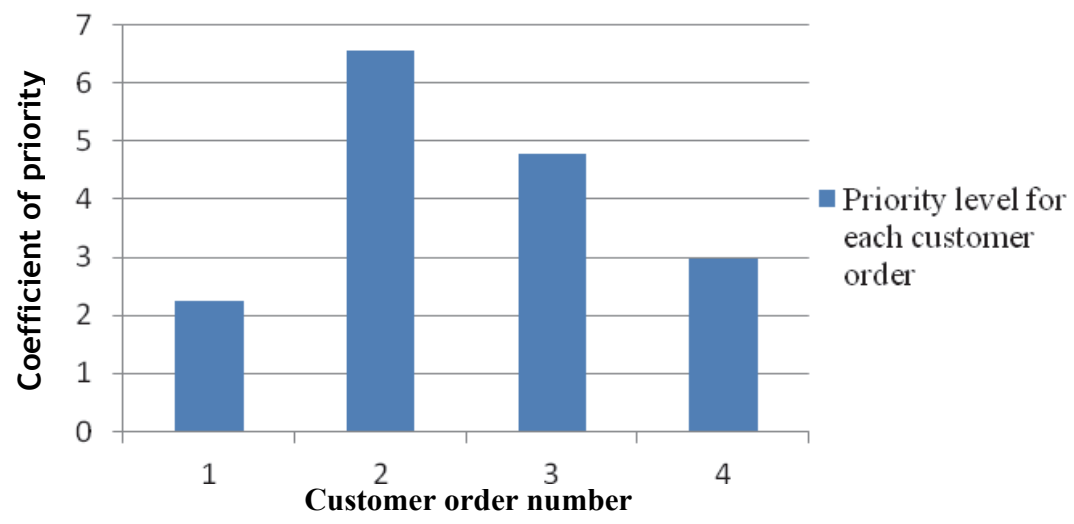

Figure 7: Graph showing priority level for each customer order

According to the input of customer orders from the GUI, the intelligent software-based production schedule evaluated and performed calculations based on the prioritisation coefficient $\left(C_{\text {priority }}\right)$. The scheduling consisted of a sorting algorithm that determined the priority level for each customer order. Together with the described RCIM cell architecture, it provided optimum production efficiency in a frequently-changing environment for scheduling manufacturing [14].

Following a completed simulation, detailed results were generated. Results were viewed in the form of a pie chart or graph. Pie charts were animated during the simulation. They provided results that were instantaneous with equipment performance. The pie chart in Figure 8 - randomly captured during the course of the simulation - represents the performance of the CNC machine. Highlighted performances, including processing and setup, were analysed. Setup was in response to the CNC changeover for the manufacture of different parts.

The graph in Figure 9 illustrates the CNC processing time for each part. It was mapped using an hourly time frame in order to display the entire simulation.

By manipulating the time frame within the Simio framework, the user can extract and analyse part-processing behaviour in timeframes of a minute or a second. The time difference from when a part enters the CNC machine to when it exits represents the CNC processing time for each part. Extended timeframes (horizontal lines) were due to the CNC changeover for the manufacture of different part types. It highlighted part buffering at the CNC input station until the machine changeover was complete. As illustrated in Figure 9, the first ten parts to be processed represented part A. The extended length of time after processing the tenth part represented the CNC machine changeover in order to meet the requirements to manufacture part $D$. Fifteen parts of part $D$ were processed, followed by five of part $C$. There were no significant extended time lengths between the processing of parts $D$ and $C$. After processing part $C$, another changeover was required due to the different characteristics between parts $C$ and $B$. 

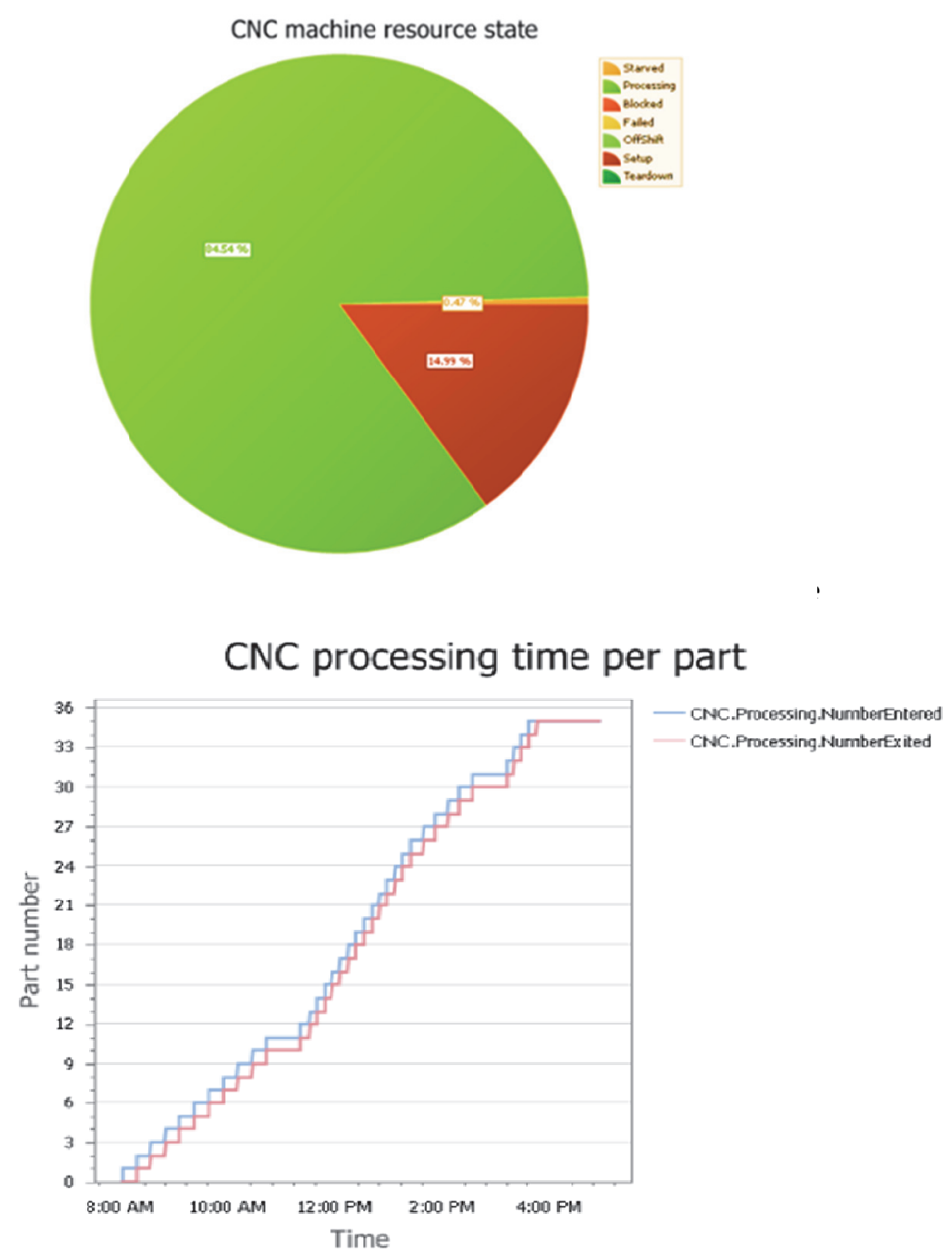

Figure 10 shows a Simio-generated detailed report for the CNC machine. It lists manufacturing aspects such as the number of parts processed (units allocated), total processing time to produce the total units allocated, and the CNC machine setup time

\section{CONCLUSION}

A hybrid RCIM cell approach aided the modern dynamic market demand for producing mass customised products. Scheduled products could be further customised and quantities varied without an increase in production cost. It provided a way to increase the variety of products offered by a company. This hybrid cell met the requirement to respond to stochastic market behaviour that continuously demands cost-effective customised products. It provided a way for manufacturing industries to be competitive in the current global market, enabling the added benefits of cost effectiveness, shorter lead times, and reduced equipment cost. 


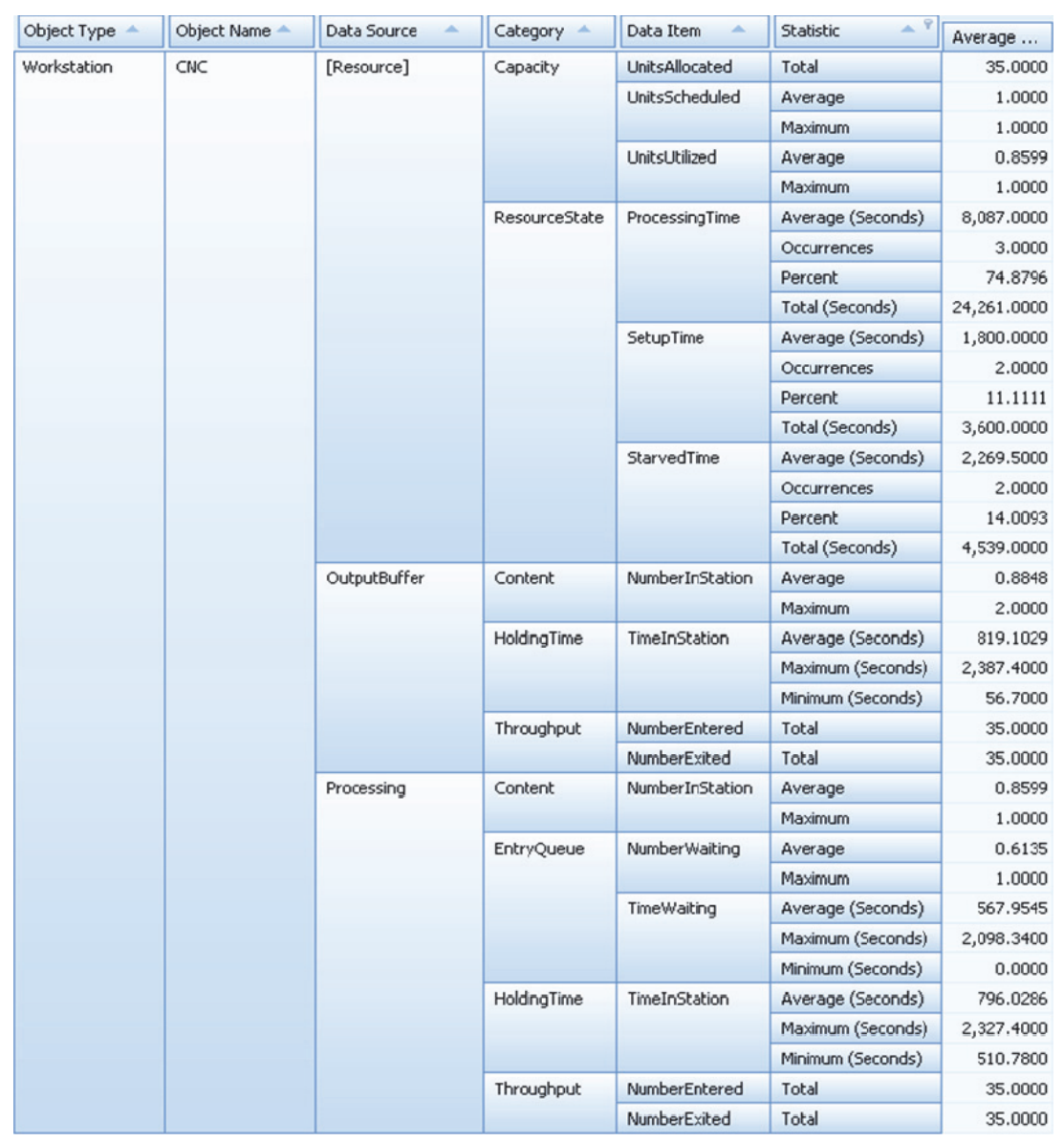

Figure 10: Simio report for the CNC machine

\section{REFERENCES}

[1] Setchi, R.M. \& Lagos, N. 2004. Reconfigurability and reconfigurable manufacturing systems: State-of-the-art review. Industrial Informatics, 529-535.

[2] Mehrabi, M.G., Ulsoy, A.G. \& Koren, Y. 2000. Reconfigurable manufacturing systems: Key to future manufacturing. Journal of Intelligent Manufacturing, 403-419.

[3] Groover, M.P. 2008. Automation, production systems, and computer-integrated manufacturing ( $3^{\text {rd }}$ ed.), New Jersey: Pearson Education Inc.

[4] Al-Ahmari, A.M.A. 2007. Evaluation of CIM technologies in Saudi industries using AHP. International Journal of Advanced Manufacturing Technology, 736-747.

[5] Nagalingam, S.V. \& Lin, G.C.I. 2008. CIM - still the solution for manufacturing industry. Robotics and Computer-Integrated Manufacturing, 24, 332-344.

[6] Yurdakul, M. 2004. Selection of computer-integrated manufacturing technologies using a combined analytic hierarchy process and goal programming model. Robotics and ComputerIntegrated Manufacturing, 20, 329-340.

[7] Yin, J.Z. 2002. Relating learning capability to the success of computer-integrated manufacturing. Technological Forecasting \& Social Change, 69, 53-70.

[8] Stoian, C. \& Frumusanu, G. 2007. Reconfigurable manufacturing systems design principles. The annals "Dunareae de jos" of galati fascicle $v$, Technologies in Mechanical Engineering, 62-65.

[9] Malhotra, V., Raj, T. \& Arora, A. 2009. Reconfigurable manufacturing system: An overview. International Journal of Machine Intelligence, 1(2), 38-46.

[10] Malhotra, V., Raj, T. \& Arora, A. 2010. Excellent techniques of manufacturing systems: RMS and FMS. International Journal of Engineering Science and Technology, 2, 137-142. 
[11] Shivanand, H.K., Benal, M.M. \& Koti, V. 2006. Flexible manufacturing system, New Delhi: New Age International.

[12] Nambiar, A.N. 2009. Mass customization: Where do we go from here? Proceedings of the World Congress on Engineering.

[13] Pollard, D., Chuo, S. \& Lee, B. 2008. Strategies For mass customization. Journal of Business \& Economics Research, 6, 77-86.

[14] Hassan, N. \& Bright, G. 2010. Optimum mass customised part production via reconfigurable computer integrated manufacturing cells. $25^{\text {th }}$ International Conference of CAD/CAM, Robotics \& Factories of the Future Conference, Pretoria.

[15] Koren, Y., Heisel, U., Jovane, F., Moriwaki, T., Pritschow, G., Ulsoy, G. \& Van Brussel, H. 1999. Reconfigurable manufacturing systems. Annals of the CIRP, 527-540.

[16] ElMaraghy, H.A. 2006. Flexible and reconfigurable manufacturing systems paradigms. International Journal of Flexible Manufacturing Systems, 17, 261-276.

[17] Lin, C.R. \& Tsao, Y. 2006. Dynamic availability-oriented control of the automated storage/retrieval system. A computer integrated manufacturing perspective. International Journal of Advanced Manufacturing Technology, 29, 948-961.

[18] Walker, A.J. 2008. Autonomous mobile materials handling platform architecture for mass customisation. Mechanical Engineering, University of KwaZulu-Natal.

[19] Lim, M.K. \& Zhang, Z. 2003. A multi-agent based control strategy for response manufacturing. Journal of Materials Processing Technology, 139, 379-384. 